\title{
Original article \\ Association between sedentary behavior and anthropometric and metabolic profiles among adolescents
}

\author{
Roseane de Fátima Guimarães \\ Michael Pereira da Silva \\ Oldemar Mazzardo \\ Rafael Vieira Martins \\ Wagner de Campos \\ Federal University of Paraná, Brazil
}

\begin{abstract}
The purpose of this study was to establish the association between sedentary behavior and the anthropometric and metabolic profiles within a sample group of 572 adolescents from public schools in the city of Curitiba, State of Paraná, Brazil. Approximately $8 \mathrm{ml}$ of blood was drawn to measure total cholesterol (TC), LDL-c, HDL-c, triglycerides, and glucose. Stature and body mass were measured to calculate the body mass index. Information about the subjects' socioeconomic status, physical activity level, sedentary behavior, eating frequency, as well as personal information was obtained through questionnaires. Descriptive statistics, measures of central tendency and percentage score, and Binary Logistic Regression were used to obtain the odds ratio with a CI of $95 \%$ and $p<0.05$. Half of the girls had TC levels classified as borderline or altered, and total screen time presented a significant association between the metabolic variables analyzed in the study. We conclude that girls had TC levels less favorable than that of the boys and that screen time is associated with some metabolic variables.
\end{abstract}

Keywords: sedentary behavior, anthropometric profile, metabolic profile, adolescents

Resumo- “Associação entre comportamento sedentário e perfil antropométrico e metabólico entre adolescentes." O objetivo deste estudo foi verificar a associação entre o comportamento sedentário e o perfil antropométrico e metabólico em uma amostra de adolescentes de Curitiba, Paraná. Participaram da pesquisa 572 adolescentes da rede pública de ensino. Coletou-se aproximadamente $8 \mathrm{ml}$ de sangue para determinar o colesterol total (CT), lipoproteína de baixa densidade, lipoproteína de alta densidade, triglicerídeos e glicemia. Mensurou-se a estatura e massa corporal para cálculo do índice de massa corporal. Obteve-se dados sobre informações pessoais, nível socioeconômico, nível de atividade física, comportamento sedentário e frequência alimentar através de questionários auto preenchidos. Utilizou-se estatística descritiva, medidas de tendência central e proporção, e a Regressão Logística Binária para obtenção do razão de chances com intervalo de confiança de $95 \%$ e $p<0,05$. Metade das moças apresentou alterações no CT e houve uma associação positiva significativa entre o tempo total de tela e as variáveis metabólicas avaliadas no estudo. Conclui-se que as meninas mostraram valores de CT menos favorável que os rapazes e, existe uma correlação entre o tempo de tela e algumas variáveis metabólicas.

Palavras-chaves: comportamento sedentário, perfil antropométrico, perfil metabólico, adolescentes

Resumen-“Asociación entre sedentarismo y los perfiles metabólicos y antropométricos en adolescentes." El objetivo fue investigar la asociación entre el comportamiento sedentario y el perfil antropométrico y metabólico en adolescentes en la ciudad de Curitiba, Paraná. Los participantes fueron 572 adolescentes matriculados en las escuelas públicas. Se recogieron $8 \mathrm{ml}$ de sangre para determinar el colesterol total (CT), LDL-c, HDL-c, triglicéridos y glucosa. Se midió la altura y el peso para calcular el índice de masa corporal. Los datos sobre la información personal, el nivel socioeconómico, el nivel de actividad física, el sedentarismo y el consumo alimentario se recogieron a través de cuestionarios auto-completados. Se empleó la estadística descriptiva, medidas de tendencia central y de proporción, y la regresión logística binaria para obtener la odds ratio con intervalo de confianza del 95\% y $\mathrm{p}<0,05$. La mitad de las chicas tenían el colesterol alto y existe una asociación positiva significativa entre el tiempo total de pantalla y las variables metabólicas evaluadas en el estudio. Llegamos a la conclusión de que las chicas presentan el CT menos favorable que los niños y el tiempo total de pantalla corresponde a las variables metabólicas.

Palabras claves: comportamiento sedentario, antropometría, perfil metabólico, adolescentes 


\section{Introduction}

Sedentary behavior, inadequate diets and lack of physical activity are considered risk factors associates with changes in the anthropometric and metabolic profiles in adolescents (Dietz, 1993; Pinho, 1999; SBC, 2005; Suñe, Dias-Da-Costa, Olinto \& Pattussi 2007).

According to the American Academy of Pediatrics (2001), sedentary behavior in adolescents is characterized by spending more than two hours a day making use of media communication and electronic entertainment. Currently, research studies have classified this behavior incidence as three or more hours of screen time viewing (Eaton et al., 2010; Tenório et al., 2010), as well as four or more hours a day (Silva et al., 2009). These findings show that this behavior is observed in Brazilian adolescents and around the world. Some of risk factors can be reduced with regular physical activity and with improved dietary habits. Excess body fat and high levels of lipids and glucose in the blood (Oliveira, Silva, Santos, Silva \& Conceição, 2005) are significantly associated with sedentary habits in adolescence (Pinho, 1999; Suñe et al., 2007).

A study conducted with adolescents in New Zealand by Hancox Milne and Poulton (2004) found a significant relationship between excessive television watching and smoking, limited capabilities for sports, and high cholesterol levels and obesity in adulthood. In agreement, Utter, Scragg and Schaaf (2006) observed a negative influence of sedentary habits on dietary habits, evidencing a high fat intake by the adolescents who spent excessive amounts of time engaged in sedentary activities.

Investigations attempting to relate sedentary behavior with anthropometric and metabolic profiles in adolescents still seek for evidences of incidence in the Brazilian population. Such literature will serve as the basis for future community interventions that aim at improving adolescents' quality of life and maintaining it through adulthood. Therefore, the more knowledge we gather about the possible relationship between sedentary behavior, regular physical activity, adequate dietary habits and anthropometric and metabolic profiles, the greater the contribution and incentive for improving daily healthy habits. Healthy habits decrease the incidence of non-transmittable chronic disease caused by risk factors for health deterioration, and consequently reduce the adult mortality rate.

Other than the aforementioned reasons, this study is also justified by the gap that exists in the literature regarding research on regional demographics of adolescents, involving a significant number of variables, including blood levels. Therefore, the purpose of this study is to determine differences between gender and age groups, as well as association between sedentary behavior and anthropometric and metabolic profiles in a sample of adolescents in the city of Curitiba, State of Paraná, Brazil.

\section{Method}

This is a non-probabilistic cross-sectional study with a descriptive-correlational design. A sample of adolescents ages ranging from 12 to 17.9 years was selected from the year 2011 final grades of middle school and from high school of the State schools system (i.e., Núcleo Regional do Estado/State Regional Education Office, in full, at the Setor Matriz/Head Sector) from the city of Curitiba, State of Paraná, Brazil.

The sample size was calculated in agreement with Suñe et al. (2007), using the software Statcalc, which gives a disease frequency estimation (in this case, the overweight condition) for the non-exposed of $10 \%$ relative risk of 2.0 for the variables; power of $80 \% ; \alpha=0.05$ and loss or refusal projection of $20 \%$, considering a minimum sample of 526 adolescents from the public schools in Curitiba. The projected sample for the data collection process resulted in valid data of 572 participants, i.e., students from 15 public schools located in the central urban area of Curitiba.

The data collection was carried out from March to October, 2012. After getting authorization from the schools, two days prior to data collection Informed Parental Consent Forms (IPCFs) were sent to parents/ caretakers for authorization of participation. The data collection took place in the schools during school hours and was coordinated by the principal researcher and collaborators.

Once IPCFs were signed, the study procedures were explained to the participants, especially information about the importance of observing a 12-hour fast before drawing the blood sample. Blood samples were always taken first prior remaining data collection from the study's protocol. Drawing of the blood was performed by a professional technician from a local certified clinical laboratory specifically contracted for the study. From each subject approximately 8 $\mathrm{ml}$ of blood was drawn and immediately stored for transport. The automated enzymatic colorimetric method was used to measure total cholesterol (TC), high density lipoprotein (HDL-c), and triglycerides (TG), whereas low density lipoprotein (LDL-c) was calculated using Friedewald, Levy and Fredrickson's formula (1972) (LDL-c = TC-HDL - TG/ $5)$. Based on the results, the subjects' lipid profiles were determined. The participants' glucose profiles were also obtained through analysis of their glucose levels using the Automated Humanstar80 method. For the classification of the lipid and glucose profiles, reference values proposed for children and adolescents in the First Childhood and Adolescence Atherosclerosis Prevention Directive (I Diretriz de Prevenção da Aterosclerose na Infância e Adolescência) (SBC, 2005) were used in order to classify normal, limitrophe and elevated results, i.e., desirable, limitrophe and altered levels as follows: TC $<150 \mathrm{mg} / \mathrm{dL}, 150-169 \mathrm{mg} / \mathrm{dL}$ and $\geq 170 \mathrm{mg} / \mathrm{dL} ; \mathrm{LDL}-\mathrm{c}<100 \mathrm{mg} / \mathrm{dL}, 100-129 \mathrm{mg} / \mathrm{dL}$ and $\geq 130 \mathrm{mg} / \mathrm{dL} ; \mathrm{HDL}-\mathrm{c} \geq 45 \mathrm{mg} / \mathrm{dL}$ and $<45 \mathrm{mg} / \mathrm{dL} ; \mathrm{TG}$ $<100 \mathrm{mg} / \mathrm{dL}, 100-129 \mathrm{mg} / \mathrm{dL}$ and $\geq 130 \mathrm{mg} / \mathrm{dL}$; and GLI $<100$ $\mathrm{mg} / \mathrm{dL}, 100-125 \mathrm{mg} / \mathrm{dL}$ and $\geq 126 \mathrm{mg} / \mathrm{dL}$. The glucose levels were indicated as normal and limitrophe/elevated because of the few number of adolescents identified within the normal classification. 
Subsequently, body mass variables and stature were measured to determine the Body Mass Index (BMI = Body Mass (kg) / Stature $\left.(\mathrm{m})^{2}\right)$, in agreement with Guedes and Guedes'(2006) measurements protocol. For the classification of the BMI, the reference tables proposed by Cole (2000) were used, separating groups by sex and age.

Questionnaires on personal information and socioeconomic status, physical activity level, sedentary behavior, and dietary habits were then administered in a classroom. After handing them out, the researchers read the questionnaires out loud for the adolescents, instructing them on how to correctly complete the questionnaires.

Social class was determined using the Brazilian Research Companies Association Questionnaire (Questionário da Associação Brasileira das Empresas de Pesquisa) (ABEP, 2008). No individuals were classified into low income class (E). The adolescents were grouped in two classes: high (A1, A2, B1, and B2) and average income class (C1, C2, and D).

The physical activity level was assessed through the short version of the International Physical Activity Questionnaire (IPAQ) (Guedes, Lopes \& Guedes, 2005). IPAC is comprised of six questions about frequency of walking, enrollment in moderate physical activity and enrollment in vigorous physical activity. The students were asked to recall the amount of time spent in physical activity by estimating the intensity level, number of days, and daily average time spent exercising during the previous week. The resulting data was classified into quartiles: Q1 = extremely active, Q2= active, Q3 = moderately active, and Q4 = insufficiently active.

The participants' sedentary behavior patterns were determined using the Adolescent Sedentary Activity Questionnaire (QASA - Guimarães, da Silva, Legnani \& Campos, 2012). QASA is comprised of 13 items divided into five categories of sedentary activities (electronics, educational, transportation, cultural and social). Participants informed the amount of time spent in each category of sedentary activity reporting the hours and/or minutes they spent throughout the week. The time spent in each sedentary activity category was calculated in minutes and computed the total time, which was the sum of all reported categories of sedentary activities. These calculations were separated for weekdays and weekends. The results were stratified into groups of sex and age. The total times spent with the weekly activities were organized in quartiles.

The dietary habits were obtained by means of the Simplified Eating Frequency Questionnaire (Questionário Simplificado de Frequência Alimentar) (Chiara \& Sichieri 2001). This questionnaire is comprised of nine items related to elevated saturated fat content and increased risk for coronary disease. Data about nutrition habits were classified dichotomously in normal (total score $\leq 100$ ) and altered scores (total score >100). The students were instructed to recall type of food they consumed daily and to inform intake frequency.

Data from this study were processed using the Epidata
3.1 and then exported into the SPSS 17.0 for statistical analyses. Kolmogorov-Smirnov normality test was calculated to identify whether or not data were normally distributed. Descriptive statistics (median and minimum/maximum), absolute frequency $(\mathrm{N})$, and relative frequency $(\%)$ were employed. In order to analyze relationships between sex and the study's variables, adolescents were divided into groups according to their classification for age (normal and altered, quartiles). Fisher Exact test was used when two classifications systems were compared. Chi-square test was used for three or more classification comparisons. For age group comparisons, the Kruskal-Wallis test and MannWhitney post-hoc with Bonferroni correction were employed.

Finally, a multivariate analysis was performed using the Binary Logistic Regression in order to obtain the odd ratios of individuals who showed anthropometric and metabolic profiles associated with the aspects of sedentary behavior. We controlled variables such as sex, age groups, socioeconomic status (SES), moderate to vigorous physical activity level (MVPA), and food score. The significance level was $5 \%$.

The metabolic variables were qualified as normal, limitrophe/elevated and the BMI was classified as normal, overweight/obese since alterations would be considered as risk factors to the adolescents' health.

This study was approved by the Federal University of Paraná's Ethics Committee on Research (CAAE: 0164.0.091.000-11). Parents/caretakers of the adolescents granted authorization for them to take part in the study.

\section{Results}

The main results of this study are presented in Table 1. Distribution of the subjects was divided by sex, classification of the study's variables, and comparisons between the genders. In the present sample, $30.5 \%$ of the boys and $27 \%$ of the girls were overweight or obese.

Regarding the food risk variable, $57.7 \%$ of the male participants and $59.8 \%$ of the female participants were classified as having cardiovascular alterations. Exactly half of the girls $(50 \%)$ had the TC classified as limitrophe or elevated. $66 \%$ of the girls had altered HDL-c, whereas $67.5 \%$ of the boys had altered HDL-c.

Significant difference between the sexes was observed for the TC variable. When compared to the boys, the girls showed higher percentage of TC alterations (Table 1).

When comparing the age groups, variable TRI showed a significant difference between the age groups 12-13.9 and 14-15.9 years, with $p=0.01$. Therefore, this result demonstrates that the younger adolescents showed higher levels for the TRI values. The descriptive data of the participants was separated by sex and age group (median, and minimum and maximum values) and can be found in Table 2 .

Table 3 shows the results for the odd ratios of altered BMI and metabolic profiles using the Total Time (T.T.) of sedentary behavior. Due to the fact that the glucose level was not significantly present in the sample, we excluded it 
Table 1. Participants distribution by sex and the variables classification.

\begin{tabular}{|c|c|c|c|c|c|c|}
\hline \multirow{2}{*}{ Variables } & & \multicolumn{2}{|c|}{ Boys } & \multicolumn{2}{|c|}{ Girls } & \multirow[b]{2}{*}{$p$ value } \\
\hline & & $\mathrm{N}$ & $\%$ & $\mathrm{~N}$ & $\%$ & \\
\hline Sex & & 246 & 43 & 326 & 57 & \multirow{4}{*}{0.64} \\
\hline \multirow{3}{*}{ Age } & $12-13.9$ & 59 & 24.0 & 86 & 26.4 & \\
\hline & $14-15.9$ & 118 & 48.0 & 159 & 48.8 & \\
\hline & $16-17.9$ & 69 & 28.0 & 81 & 24.8 & \\
\hline \multirow{2}{*}{ SES } & Medium $(\mathrm{C} 1, \mathrm{C} 2, \mathrm{D})$ & 174 & 70.7 & 243 & 74.5 & \multirow{2}{*}{0.34} \\
\hline & $\operatorname{High}(\mathrm{A} 1, \mathrm{~A} 2, \mathrm{~B} 1, \mathrm{~B} 2)$ & 72 & 29.3 & 83 & 25.5 & \\
\hline \multirow[t]{2}{*}{ Food score } & Normal & 104 & 42.3 & 131 & 40.2 & \multirow[b]{2}{*}{0.66} \\
\hline & Elevated & 142 & 57.7 & 195 & 59.8 & \\
\hline \multirow{3}{*}{ BMI } & Normal & 171 & 69,2 & 238 & 73,0 & \multirow{3}{*}{0.61} \\
\hline & Overweight & 54 & 21,9 & 62 & 19,0 & \\
\hline & Obese & 22 & 8,9 & 26 & 8,0 & \\
\hline \multirow{3}{*}{ TC } & Normal & 153 & 61,9 & 163 & 50,0 & \multirow{3}{*}{$0.01 *$} \\
\hline & Limitrophe & 55 & 22,3 & 94 & 28,8 & \\
\hline & Elevated & 39 & 15,8 & 69 & 21,2 & \\
\hline \multirow{3}{*}{ LDL-c } & Normal & 172 & 69,6 & 200 & 61,3 & \multirow{3}{*}{0.09} \\
\hline & Limitrophe & 65 & 26,3 & 113 & 34,7 & \\
\hline & Elevated & 10 & 4,0 & 13 & 4,0 & \\
\hline \multirow[b]{2}{*}{ HDL-c } & Normal & 80 & 32.5 & 111 & 34.0 & \multirow{2}{*}{0.72} \\
\hline & Altered & 166 & 67.5 & 215 & 66.0 & \\
\hline \multirow{3}{*}{ TG } & Normal & 221 & 89,5 & 295 & 90,5 & \multirow{3}{*}{0.90} \\
\hline & Limitrophe & 17 & 6,9 & 21 & 6,4 & \\
\hline & Elevated & 9 & 3,6 & 10 & 3,1 & \\
\hline \multirow{2}{*}{ GLI } & Normal & 243 & 98.8 & 326 & 100.0 & \multirow{2}{*}{$0.04 *$} \\
\hline & Limitrophe/Elevated & 3 & 1.2 & 0 & 0 & \\
\hline
\end{tabular}

Sex differences calculated by Fisher's Exact Test (two classifications) or Chi-Square Test (three or more classifications). *Significantly $(p<.05)$ for Fisher's Exact Test.

from analysis. Quartile 1 was used as reference because it classifies individuals with less time spent with sedentary activities within the sample.

The multivariate regression analysis showed a significant positive association between TC and the increase of the quartiles of TT in the category electronic sedentary activity (i.e., subjects who were in quartiles 2, 3, and 4 showed a higher chance of having their TC altered when compared to quartile 1). Additionally, a significant positive association was also found between LDL-c and the quartiles of increased TT in the category electronic.

A negative (protective) association was noticed between HDL-c and the last two quartiles of TT in the category electronic [quartile 3: OR $0.54($ CI 95\% = 0.31-0.94)] and [quartile 4: OR 0.51 (CI 95\% = 0.29-0.88)]. Another significant negative association was observed between the BMI and the total sedentary time in the last quartile [quartile 4: OR $0.56($ CI $95 \%=0.33-0.96)]$.

\section{Discussion}

Our results showed that, in general, at least half of the boys and half of the girls have satisfactory MVPA levels, according to the World Health Organization's recommendations (2010) of 60 minutes of daily physical activity. However, in spite of such relevant findings, we 
Table 2. Sample characteristics by sex and age group $(\mathrm{N}=572)$.

\begin{tabular}{|c|c|c|c|c|c|c|}
\hline \multirow[b]{2}{*}{ Age } & \multicolumn{3}{|c|}{ Male } & \multicolumn{3}{|c|}{ Female } \\
\hline & $12-13.9$ & $14-15.9$ & $16-17.9$ & $12-13.9$ & $14-15.9$ & $16-17.9$ \\
\hline Variables & $\begin{array}{c}\text { Median } \\
(\text { Min - Max })\end{array}$ & $\begin{array}{c}\text { Median } \\
(\text { Min - Max) }\end{array}$ & $\begin{array}{c}\text { Median } \\
(\text { Min - Max) }\end{array}$ & $\begin{array}{c}\text { Median } \\
(\text { Min - Max })\end{array}$ & $\begin{array}{c}\text { Median } \\
(\text { Min - Max })\end{array}$ & $\begin{array}{c}\text { Median } \\
(\text { Min - Max) }\end{array}$ \\
\hline $\begin{array}{l}\text { T.T Sedentary } \\
\text { weekly (min) }\end{array}$ & $\begin{array}{c}4800 \\
(1590-12055)\end{array}$ & $\begin{array}{c}5215 \\
(2225-8235)\end{array}$ & $\begin{array}{c}5458 \\
(1336-8880)\end{array}$ & $\begin{array}{c}5305 \\
(1940-10150)\end{array}$ & $\begin{array}{c}5065 \\
(1605-10050)\end{array}$ & $\begin{array}{c}5135 \\
(1785-9425)\end{array}$ \\
\hline $\begin{array}{l}\text { MVPA weekly } \\
(\min )\end{array}$ & $\begin{array}{c}520 \\
(20-3270)\end{array}$ & $\begin{array}{c}480 \\
(0-2400)\end{array}$ & $\begin{array}{c}600 \\
(0-2580)\end{array}$ & $\begin{array}{c}420 \\
(0-2410)\end{array}$ & $\begin{array}{c}330 \\
(0-4590)\end{array}$ & $\begin{array}{c}260 \\
(0-1930)\end{array}$ \\
\hline Food score & $\begin{array}{c}128.5 \\
(49-314)\end{array}$ & $\begin{array}{c}111.5 \\
(15.5-481)\end{array}$ & $\begin{array}{c}107 \\
(19-281)\end{array}$ & $\begin{array}{c}117 \\
(25-345)\end{array}$ & $\begin{array}{c}113 \\
(7-409)\end{array}$ & $\begin{array}{c}111.5 \\
(26-393)\end{array}$ \\
\hline BMI $\left(\mathrm{kg} / \mathrm{m}^{2}\right)$ & $\begin{array}{c}20.9 \\
(15.6-36.3)\end{array}$ & $\begin{array}{c}20.7 \\
(13.7-34.5)\end{array}$ & $\begin{array}{c}21.6 \\
(15.3-37.9)\end{array}$ & $\begin{array}{c}21.3 \\
(15.6-31)\end{array}$ & $\begin{array}{c}21.4 \\
(15-46.6)\end{array}$ & $\begin{array}{c}21 \\
(16.2-58.8)\end{array}$ \\
\hline $\mathrm{TC}(\mathrm{mg} / \mathrm{dl})$ & $\begin{array}{c}146 \\
(119-232)\end{array}$ & $\begin{array}{c}142,5 \\
(108-227)\end{array}$ & $\begin{array}{c}141 \\
(110-223)\end{array}$ & $\begin{array}{c}147 \\
(120-249)\end{array}$ & $\begin{array}{c}154 \\
(118-241)\end{array}$ & $\begin{array}{c}149 \\
(121-201)\end{array}$ \\
\hline LDL-c (mg/dl) & $\begin{array}{c}92,6 \\
(61-162)\end{array}$ & $\begin{array}{c}90 \\
(54-152)\end{array}$ & $\begin{array}{c}94 \\
(70-165)\end{array}$ & $\begin{array}{c}90.6 \\
(70-172)\end{array}$ & $\begin{array}{c}97.8 \\
(62-173)\end{array}$ & $\begin{array}{c}98.4 \\
(73-127)\end{array}$ \\
\hline HLD-c (mg/dl) & $\begin{array}{c}44 \\
(30-62)\end{array}$ & $\begin{array}{c}39 \\
(28-62)\end{array}$ & $\begin{array}{c}38 \\
(29-57)\end{array}$ & $\begin{array}{c}42 \\
(31-60)\end{array}$ & $\begin{array}{c}41 \\
(30-60)\end{array}$ & $\begin{array}{c}40 \\
(30-64)\end{array}$ \\
\hline $\mathrm{TG}(\mathrm{mg} / \mathrm{dl})$ & $\begin{array}{c}54 \\
(33-133)\end{array}$ & $\begin{array}{c}57 \\
(32-214)\end{array}$ & $\begin{array}{c}58 \\
(32-200)\end{array}$ & $\begin{array}{c}62 \\
(31-190)\end{array}$ & $\begin{array}{c}60 \\
(32-270)\end{array}$ & $\begin{array}{c}58 \\
(36-150)\end{array}$ \\
\hline GLI (mg/dl) & $\begin{array}{c}86 \\
(67-100)\end{array}$ & $\begin{array}{c}84 \\
(65-102)\end{array}$ & $\begin{array}{c}82 \\
(65-97)\end{array}$ & $\begin{array}{c}82 \\
(71-98)\end{array}$ & $\begin{array}{c}83 \\
(60-93)\end{array}$ & $\begin{array}{c}72 \\
(66-97)\end{array}$ \\
\hline
\end{tabular}

Min: Minimum Value; Max: Maximum Value; T.T.: Total Time; min: Minutes; MVPA: Moderate to Vigorous Physical Activity; BMI: Body Mass Index; TC: Total Cholesterol; LDL-c: Low density lipoprotein; HDL-c: High density lipoprotein; TG: Triglycerides.

observed that a large number of adolescents who took part in the study spend a lot of time engaged in sedentary behavior. This result adds to the fact that the adolescents in the present sample, despite of choosing high levels of sedentary activities, can be considered physically active, therefore, achieving the recommended MVPA levels of health conditions.

In this study's sample, a high percentage of overweight and obese subjects was found, $30.5 \%$ and $27 \%$ of the boys and girls. Their BMI was categorized, according to Cole's classification system (Cole, 2000). The prevalence of overweight and obesity found among boys confirms findings by Balaban and da Silva (2001), conducted in the city of Recife, State of Pernambuco, Brazil, in which a prevalence of $35.7 \%$ of overweight and of $9.7 \%$ of obesity was detected for boys.

Percentages of elevated BMI in this study are higher than results found in studies conducted in the South region of Brazil (Bozza et al., 2009; Terres, Pinheiro, Horta, Pinheiro \& Horta, 2006). However, some similarities exist with the study by Suñe et al. (2007), who found $27.8 \%$ of overweight and $21.6 \%$ obesity for the boys and girls from the State of Rio Grande do Sul, Brazil and with findings by Guedes, Guedes, Barbosa, Oliveira and Stanganelli (2006), who found overweight and obesity rates of $30.6 \%$ for girls and $26 \%$ for boys (7-18 years of age) from the North region of the State of Paraná, Brazil. These results suggest that incidences of overweight and obesity are similar in individuals from the capital cities and from the North region of the State of Paraná.

Another risk factor to consider is the percentage of individuals classified as having inadequate food habits. Of all the adolescents, $57.7 \%$ of the boys and $59.8 \%$ of the girls scored above 100 points, which is considered elevated consumption of food with high fat content, as well as is considered to be associated with risk for coronary diseases (Chiara \& Sichieri, 2001). High percentages also appeared in the study of Stabelini Neto (2011), who utilizing the same food intake frequency assessment protocol showed that virtually half $(50 \%)$ of the adolescents from a town in the state of Paraná had inadequate eating habits.

High percentages of altered HDL-c, for both genders, were observed. Campos et al. (2010), although having used threshold values for classification of lipid alterations that were higher than the ones used in this study, also found high incidence of altered HDL-c among adolescents, 54.8\% among males and $38.7 \%$ among females.

Studies outside of Brazil also showed high incidence 


\begin{tabular}{|c|c|c|c|c|c|c|c|c|c|c|}
\hline \multirow[b]{3}{*}{ Variables } & \multicolumn{2}{|c|}{ BMI $\left(\mathrm{kg} / \mathrm{m}^{2}\right)$} & \multicolumn{2}{|c|}{ TC (mg/dl) } & \multicolumn{2}{|c|}{ LDL-c (mg/dl) } & \multicolumn{2}{|c|}{ HDL-c (mg/dl) } & \multicolumn{2}{|c|}{ TG (mg/dl) } \\
\hline & Unadjusted & Adjusted & Unadjusted & Adjusted & Unadjusted & Adjusted & Unadjusted & Adjusted & Unadjusted & Adjusted \\
\hline & $\begin{array}{c}\mathrm{OR} \\
(\mathrm{CI} 95 \%)\end{array}$ & $\begin{array}{c}\mathrm{OR} \\
\text { (CI 95\%) }\end{array}$ & $\begin{array}{c}\mathrm{OR} \\
\text { (CI 95\%) }\end{array}$ & $\begin{array}{c}\text { OR } \\
\text { (CI 95\%) }\end{array}$ & $\begin{array}{c}\text { OR } \\
\text { (CI 95\%) }\end{array}$ & $\begin{array}{c}\text { OR } \\
\text { (CI 95\%) }\end{array}$ & $\begin{array}{c}\text { OR } \\
\text { (CI 95\%) }\end{array}$ & $\begin{array}{c}\text { OR } \\
\text { (CI 95\%) }\end{array}$ & $\begin{array}{c}\text { OR } \\
\text { (CI 95\%) }\end{array}$ & $\begin{array}{c}\mathrm{OR} \\
\text { (CI 95\%) }\end{array}$ \\
\hline $\begin{array}{l}\text { T.T. Sedentar } \\
\text { Q1 }\end{array}$ & Reference & Reference & Reference & Reference & Reference & Reference & Reference & Reference & Reference & Reference \\
\hline Q2 & $\begin{array}{c}0.71 \\
(0.42-1.16)\end{array}$ & $\begin{array}{c}0.70 \\
(0.42-1.18)\end{array}$ & $\begin{array}{c}1.41 \\
(0.88-2.26)\end{array}$ & $\begin{array}{c}1.34 \\
(0.83-2.18)\end{array}$ & $\begin{array}{c}1.08 \\
(0.65-1.78)\end{array}$ & $\begin{array}{c}0.98 \\
(0.58-1.63)\end{array}$ & $\begin{array}{c}0.76 \\
(0.46-1.26)\end{array}$ & $\begin{array}{c}0.73 \\
(0.44-1.22)\end{array}$ & $\begin{array}{c}1.55 \\
(0.72-3.34)\end{array}$ & $\begin{array}{c}1.36 \\
(0.61-2.99)\end{array}$ \\
\hline Q3 & $\begin{array}{c}0.69 \\
(0.41-1.14)\end{array}$ & $\begin{array}{c}0.68 \\
(0.41-1.15)\end{array}$ & $\begin{array}{c}1.43 \\
(0.89-2.29)\end{array}$ & $\begin{array}{c}1.41 \\
(0.87-2.28)\end{array}$ & $\begin{array}{c}1.27 \\
(0.78-2.08)\end{array}$ & $\begin{array}{c}1.25 \\
(0.75-2.06)\end{array}$ & $\begin{array}{c}0.86 \\
(0.52-1.42)\end{array}$ & $\begin{array}{c}0.89 \\
(0.53-1.49)\end{array}$ & $\begin{array}{c}1.08 \\
(0.48-2.46)\end{array}$ & $\begin{array}{c}1.07 \\
(0.46-2.46)\end{array}$ \\
\hline Q4 & $\begin{array}{c}0.55 * \\
(0.33-0.93)\end{array}$ & $\begin{array}{c}0.56^{*} \\
(0.33-0.96)\end{array}$ & $\begin{array}{c}1.15 \\
(0.72-1.84)\end{array}$ & $\begin{array}{c}1.03 \\
(0.63-1.67)\end{array}$ & $\begin{array}{c}1.45 \\
(0.89-2.36) \\
\end{array}$ & $\begin{array}{c}1.31 \\
(0.79-2.17)\end{array}$ & $\begin{array}{c}0.69 \\
(0.43-1.15)\end{array}$ & $\begin{array}{c}0.71 \\
(0.42-1.18)\end{array}$ & $\begin{array}{c}1.14 \\
(0.51-2.56)\end{array}$ & $\begin{array}{c}1.02 \\
(0.44-2.35) \\
\end{array}$ \\
\hline $\begin{array}{l}\text { T.T. Education } \\
\text { Q1 }\end{array}$ & Reference & Reference & Reference & Reference & Reference & Reference & Reference & Reference & Reference & Reference \\
\hline Q2 & $\begin{array}{c}1.05 \\
(0.63-1.73)\end{array}$ & $\begin{array}{c}0.88 \\
(0.52-1.49)\end{array}$ & $\begin{array}{c}1.19 \\
(0.74-1.90)\end{array}$ & $\begin{array}{c}1.19 \\
(0.73-1.96)\end{array}$ & $\begin{array}{c}1.34 \\
(0.82-2.19)\end{array}$ & $\begin{array}{c}1.25 \\
(0.74-2.09)\end{array}$ & $\begin{array}{c}0.60^{*} \\
(0.36-0.99)\end{array}$ & $\begin{array}{c}0.61 \\
(0.36-1.01)\end{array}$ & $\begin{array}{c}1.82 \\
(0.75-4.44)\end{array}$ & $\begin{array}{c}1.76 \\
(0.70-4.42)\end{array}$ \\
\hline Q3 & $\begin{array}{c}0.75 \\
(0.45-1.27)\end{array}$ & $\begin{array}{c}0.61 \\
(0.35-1.07)\end{array}$ & $\begin{array}{c}1.18 \\
(0.74-1.89)\end{array}$ & $\begin{array}{c}1.14 \\
(0.69-1.87)\end{array}$ & $\begin{array}{c}1.71 * \\
(1.05-2.79)\end{array}$ & $\begin{array}{c}1.58 \\
(0.94-2.67)\end{array}$ & $\begin{array}{c}0.79 \\
(0.48-1.32)\end{array}$ & $\begin{array}{c}0.89 \\
(0.52-1.51)\end{array}$ & $\begin{array}{c}2.02 \\
(0.83-4.87)\end{array}$ & $\begin{array}{c}2.19 \\
(0.87-5.51)\end{array}$ \\
\hline Q4 & $\begin{array}{c}0.82 \\
(0.49-1.38)\end{array}$ & $\begin{array}{c}0.75 \\
(0.43-1.30)\end{array}$ & $\begin{array}{c}1.07 \\
(0.67-1.72)\end{array}$ & $\begin{array}{c}1.09 \\
(0.66-1.81)\end{array}$ & $\begin{array}{c}0.94 \\
(0.56-1.56)\end{array}$ & $\begin{array}{c}0.97 \\
(0.56-1.67)\end{array}$ & $\begin{array}{c}0.99 \\
(0.59-1.66)\end{array}$ & $\begin{array}{c}0.96 \\
(0.56-1.65)\end{array}$ & $\begin{array}{c}2.32 \\
(0.97-5.53)\end{array}$ & $\begin{array}{c}2.28 \\
(0.91-5.68) \\
\end{array}$ \\
\hline $\begin{array}{l}\text { T.T. Elet } \\
\text { Q1 }\end{array}$ & Reference & Reference & Reference & Reference & Reference & Reference & Reference & Reference & Reference & Reference \\
\hline Q2 & $\begin{array}{c}0.83 \\
(0.50-1.38)\end{array}$ & $\begin{array}{c}0.77 \\
(0.45-1.32)\end{array}$ & $\begin{array}{c}1.64 * \\
(1.02-2.64)\end{array}$ & $\begin{array}{c}1.68^{*} \\
(1.02-2.78)\end{array}$ & $\begin{array}{c}1.71 * \\
(1.01-2.86)\end{array}$ & $\begin{array}{c}1.72 \\
(0.99-2.97)\end{array}$ & $\begin{array}{c}0.65 \\
(0.39-1.08)\end{array}$ & $\begin{array}{c}0.69 \\
(0.40-1.20)\end{array}$ & $\begin{array}{c}1.28 \\
(0.61-2.67)\end{array}$ & $\begin{array}{c}1.38 \\
(0.63-3.05)\end{array}$ \\
\hline Q3 & $\begin{array}{c}0.89 \\
(0.54-1.49)\end{array}$ & $\begin{array}{c}0.90 \\
(0.52-1.56)\end{array}$ & $\begin{array}{c}1.94 * \\
(1.20-3.12)\end{array}$ & $\begin{array}{c}1.95^{*} \\
(1.17-3.24)\end{array}$ & $\begin{array}{c}2.27^{*} \\
(1.35-3.79)\end{array}$ & $\begin{array}{c}2.23 * \\
(1.28-3.85)\end{array}$ & $\begin{array}{c}0.53^{*} \\
(0.32-0.89)\end{array}$ & $\begin{array}{c}0.54 * \\
(0.31-0.94)\end{array}$ & $\begin{array}{c}1.07 \\
(0.49-2.31)\end{array}$ & $\begin{array}{c}1.06 \\
(0.47-2.40)\end{array}$ \\
\hline Q4 & $\begin{array}{c}0.67 \\
(0.39-1.12)\end{array}$ & $\begin{array}{c}0.64 \\
(0.36-1.13)\end{array}$ & $\begin{array}{c}1.62 * \\
(1.01-2.60) \\
\end{array}$ & $\begin{array}{c}1.72^{*} \\
(1.03-2.88)\end{array}$ & $\begin{array}{c}2.26^{*} \\
(1.36-3.77) \\
\end{array}$ & $\begin{array}{c}2.29 * \\
(1.31-3.96)\end{array}$ & $\begin{array}{c}0.51 * \\
(0.31-0.86) \\
\end{array}$ & $\begin{array}{c}0.51 * \\
(0.29-0.88) \\
\end{array}$ & $\begin{array}{c}0.66 \\
(0.28-1.54)\end{array}$ & $\begin{array}{c}0.65 \\
(0.26-1.60)\end{array}$ \\
\hline
\end{tabular}




\begin{tabular}{|c|c|c|c|c|c|c|c|c|c|c|}
\hline \multirow[b]{3}{*}{$\underline{\text { Variables }}$} & \multicolumn{2}{|c|}{ BMI $\left(\mathrm{kg} / \mathrm{m}^{2}\right)$} & \multicolumn{2}{|c|}{ TC (mg/dl) } & \multicolumn{2}{|c|}{ LDL-c (mg/dl) } & \multicolumn{2}{|c|}{ HDL-c (mg/dl) } & \multicolumn{2}{|c|}{ TG (mg/dl) } \\
\hline & Unadjusted & Adjusted & Unadjusted & Adjusted & Unadjusted & Adjusted & Unadjusted & Adjusted & Unadjusted & Adjusted \\
\hline & $\begin{array}{c}\text { OR } \\
\text { (CI 95\%) } \\
\end{array}$ & $\begin{array}{c}\text { OR } \\
\text { (CI 95\%) } \\
\end{array}$ & $\begin{array}{c}\text { OR } \\
(\mathrm{CI} 95 \%) \\
\end{array}$ & $\begin{array}{c}\text { OR } \\
(\mathrm{CI} 95 \%) \\
\end{array}$ & $\begin{array}{c}\text { OR } \\
(\mathrm{CI} 95 \%) \\
\end{array}$ & $\begin{array}{c}\mathrm{OR} \\
(\mathrm{CI} 95 \%) \\
\end{array}$ & $\begin{array}{c}\text { OR } \\
\text { (CI 95\%) } \\
\end{array}$ & $\begin{array}{c}\text { OR } \\
(\mathrm{CI} 95 \%) \\
\end{array}$ & $\begin{array}{c}\text { OR } \\
(\mathrm{CI} 95 \%) \\
\end{array}$ & $\begin{array}{c}\text { OR } \\
(\mathrm{CI} 95 \%) \\
\end{array}$ \\
\hline $\begin{array}{l}\text { T.T Transport } \\
\text { Q1 }\end{array}$ & Reference & Reference & Reference & Reference & Reference & Reference & Reference & Reference & Reference & Reference \\
\hline Q2 & $\begin{array}{c}0.98 \\
(0.59-1.65)\end{array}$ & $\begin{array}{c}1.00 \\
(0.57-1.76)\end{array}$ & $\begin{array}{c}1.22 \\
(0.76-1.95)\end{array}$ & $\begin{array}{c}1.05 \\
(0.63-1.74)\end{array}$ & $\begin{array}{c}1.23 \\
(0.74-2.01)\end{array}$ & $\begin{array}{c}1.09 \\
(0.64-1.88)\end{array}$ & $\begin{array}{c}0.64 \\
(0.39-1.05)\end{array}$ & $\begin{array}{c}0.66 \\
(0.39-1.13)\end{array}$ & $\begin{array}{c}1.45 \\
(0.65-3.25)\end{array}$ & $\begin{array}{c}1.37 \\
(0.57-3.28)\end{array}$ \\
\hline Q3 & $\begin{array}{c}0.68 \\
(0.39-1.15)\end{array}$ & $\begin{array}{c}0.71 \\
(0.39-1,28)\end{array}$ & $\begin{array}{c}1.00 \\
(0.63-1.90)\end{array}$ & $\begin{array}{c}0.89 \\
(0.54-1.49)\end{array}$ & $\begin{array}{c}1.15 \\
(0.70-1.88)\end{array}$ & $\begin{array}{c}1.08 \\
(0.63-1.86)\end{array}$ & $\begin{array}{c}0.98 \\
(0.59-1.61)\end{array}$ & $\begin{array}{c}0.96 \\
(0.55-1.65)\end{array}$ & $\begin{array}{c}0.99 \\
(0.42-2.31)\end{array}$ & $\begin{array}{c}0.95 \\
(0.38-2.38)\end{array}$ \\
\hline Q4 & $\begin{array}{c}1.22 \\
(0.74-2.03)\end{array}$ & $\begin{array}{c}1.34 \\
(0.75-2.39)\end{array}$ & $\begin{array}{c}1.19 \\
(0.74-1.60)\end{array}$ & $\begin{array}{c}1.09 \\
(0.64-1.87)\end{array}$ & $\begin{array}{c}1.32 \\
(0.80-2.16)\end{array}$ & $\begin{array}{c}1.33 \\
(0.75-2.36)\end{array}$ & $\begin{array}{c}1.17 \\
(0.70-1.95)\end{array}$ & $\begin{array}{c}1.12 \\
(0.63-2.00)\end{array}$ & $\begin{array}{c}1.61 \\
(0.73-3.55)\end{array}$ & $\begin{array}{c}1.46 \\
(0.59-3.63)\end{array}$ \\
\hline $\begin{array}{l}\text { T.T. Cultural } \\
\text { Q1 }\end{array}$ & Reference & Reference & Reference & Reference & Reference & Reference & Reference & Reference & Reference & Reference \\
\hline Q2 & $\begin{array}{c}0.88 \\
(0.53-1.48)\end{array}$ & $\begin{array}{c}0.85 \\
(0.48-1.49)\end{array}$ & $\begin{array}{c}1.53 \\
(0.95-2.45)\end{array}$ & $\begin{array}{c}1.43 \\
(0.86-2.36)\end{array}$ & $\begin{array}{c}1.33 \\
(0.81-2.16)\end{array}$ & $\begin{array}{c}1.27 \\
(0.75-2.16)\end{array}$ & $\begin{array}{c}0.66 \\
(0.40-1.08)\end{array}$ & $\begin{array}{c}0.81 \\
(0.47-1.37)\end{array}$ & $\begin{array}{c}1.11 \\
(0.51-2.40)\end{array}$ & $\begin{array}{c}1.11 \\
(0.48-2.56)\end{array}$ \\
\hline Q3 & $\begin{array}{c}0.96 \\
(0.57-1.60)\end{array}$ & $\begin{array}{c}1.04 \\
(0.59-1.84)\end{array}$ & $\begin{array}{c}1.39 \\
(0.86-2.23)\end{array}$ & $\begin{array}{c}1.30 \\
(0.77-2.18)\end{array}$ & $\begin{array}{c}1.29 \\
(0.79-2.10)\end{array}$ & $\begin{array}{c}1.15 \\
(0.67-1.98)\end{array}$ & $\begin{array}{c}0.79 \\
(0.49-1.30)\end{array}$ & $\begin{array}{c}0.91 \\
(0.52-1.56)\end{array}$ & $\begin{array}{c}0.62 \\
(0.25-1.49)\end{array}$ & $\begin{array}{c}0.53 \\
(0.20-1.36)\end{array}$ \\
\hline Q4 & $\begin{array}{c}0.91 \\
(0.54-1.53) \\
\end{array}$ & $\begin{array}{c}1.02 \\
(0.55-1.87) \\
\end{array}$ & $\begin{array}{c}1.10 \\
(0.68-1.78) \\
\end{array}$ & $\begin{array}{c}1.00 \\
(0.58-1.74) \\
\end{array}$ & $\begin{array}{c}0.85 \\
(0.51-1.42) \\
\end{array}$ & $\begin{array}{c}0.74 \\
(0.41-1.34) \\
\end{array}$ & $\begin{array}{c}1.22 \\
(0.72-2.05) \\
\end{array}$ & $\begin{array}{c}1.17 \\
(0.65-2.12) \\
\end{array}$ & $\begin{array}{c}1.43 \\
(0.67-3.01) \\
\end{array}$ & $\begin{array}{c}1.16 \\
(0.48-2.77) \\
\end{array}$ \\
\hline $\begin{array}{l}\text { T.T. Social } \\
\text { Q1 }\end{array}$ & Reference & Reference & Reference & Reference & Reference & Reference & Reference & Reference & Reference & Reference \\
\hline Q2 & $\begin{array}{c}0.95 \\
(0.57-1.56)\end{array}$ & $\begin{array}{c}0.91 \\
(0.53-1.56)\end{array}$ & $\begin{array}{c}1.07 \\
(0.67-1.72)\end{array}$ & $\begin{array}{c}1.07 \\
(0.65-1.75)\end{array}$ & $\begin{array}{c}0.86 \\
(0.52-1.41)\end{array}$ & $\begin{array}{c}0.88 \\
(0.52-1.49)\end{array}$ & $\begin{array}{c}1.13 \\
(0.68-1.87)\end{array}$ & $\begin{array}{c}1.01 \\
(0.59-1.71)\end{array}$ & $\begin{array}{c}1.18 \\
(0.54-2.58)\end{array}$ & $\begin{array}{c}1.26 \\
(0.55-2.88)\end{array}$ \\
\hline Q3 & $\begin{array}{c}0.64 \\
(0.39-1.08)\end{array}$ & $\begin{array}{c}0.64 \\
(0.37-1.11)\end{array}$ & $\begin{array}{c}1.09 \\
(0.69-1.34)\end{array}$ & $\begin{array}{c}1.09 \\
(0.67-1.79)\end{array}$ & $\begin{array}{c}1.27 \\
(0.78-2.04)\end{array}$ & $\begin{array}{c}1.25 \\
(0.75-2.08)\end{array}$ & $\begin{array}{c}0.92 \\
(0.57-1.50)\end{array}$ & $\begin{array}{c}0.84 \\
(0.49-1.41)\end{array}$ & $\begin{array}{c}1.01 \\
(0.45-2.22)\end{array}$ & $\begin{array}{c}1.06 \\
(0.45-2.47)\end{array}$ \\
\hline Q4 & $\begin{array}{c}0.71 \\
(0.43-1.19)\end{array}$ & $\begin{array}{c}0.68 \\
(0.39-1.17)\end{array}$ & $\begin{array}{c}0.83 \\
(0.52-1.74)\end{array}$ & $\begin{array}{c}0.80 \\
(0.48-1.31)\end{array}$ & $\begin{array}{c}0.80 \\
(0.49-1.31)\end{array}$ & $\begin{array}{c}0.79 \\
(0.47-1.34)\end{array}$ & $\begin{array}{c}0.88 \\
(0.54-1.44)\end{array}$ & $\begin{array}{c}0.78 \\
(0.47-1.32)\end{array}$ & $\begin{array}{c}1.14 \\
(0.52-2.50)\end{array}$ & $\begin{array}{c}1.18 \\
(0.52-2.68)\end{array}$ \\
\hline
\end{tabular}

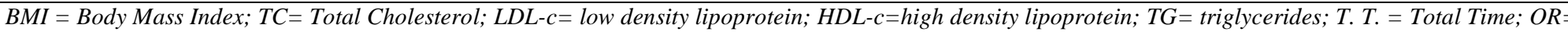

Odds Ratio; $C I=$ Confidence Interval. $* p \leq 0.05$. Values adjusted for sex, age group, SES, MVPA, food risk and all sedentary behavior aspects. 
of altered HDL-c $(\leq 40 \mathrm{mg} / \mathrm{dL}=$ alteration $)$ among youngsters based on classification by the World Health Organization and by the National Cholesterol Education Program's Adult Treatment Panel III. Sanders (2006) and Sartorio, Agosti, De Col, Mornati and Francescato (2007) showed a percentage of $75 \%$ of American and Italian adolescents with altered HDL-c. Castillo et al. (2007) found that $89.3 \%$ of Mexican adolescents of both genders show low levels of HDL-c.

Results of the HDL-c were similar to those found by Campos et al. (2010). The percentage of altered TC within the sample of this study was higher than the one found by this author (i.e., $21.3 \%$ among females). This evidence raises concern, since individuals who have altered lipid levels in the adolescence period have higher chance of keeping this result throughout adult life, making cardiovascular disease a high risk (Valverde et al. 1999).

Special attention must be given to the significant differences between altered TCs in males and females. High levels of TC were more frequent among the girls when compared to the boys. This was also observed by Faria, Dalpino and Takata (2008), Luciano (2009), Moura, De Castro, Mellin and Figueiredo (2000); Rover and Souza (2007), Srinivasan, Myers and Berenson (2002). This variation of TC values for the genders is reported by the Third Brazilian Directive on Dyslipidemias and Atherosclerosis Prevention Directive (SBC, 2001). There is a steady rise in the TC levels for women between 15 and 55 years of age, decreasing after menopause due to the protective effect of estrogen, a hormone responsible for the feminine characteristics and of great importance in the function of the menstrual cycle.

The significant difference in the TRI values for the age groups of 12-13.9 and 14-15.9 indicates that a relationship exists between TRI and food intake with high fat content. TRI is influenced by food intake and serves as energy storage in the body (SBC, 2011). Descriptive data of the present sample shows that the higher medians of the food score were found in this age group for both genders.

In summary, sedentary behavior showed a significant association with the increase of time spent with sedentary activities (particularly for the electronic category) and the TC and LDL-c levels, regardless gender, age group, SES, the level of MVPA, the food score, and other aspects of sedentary behavior. This result shows that the time spent with electronic sedentary activity (screen time) can be a risk factor for the development of hypercholesterolemia.

An unexpected negative association between the last quartile of sedentary activities (i.e., electronic category) and the HDL-c levels was observed. The same result appeared in the study by Goldfield et al. (2011) with Canadian adolescents. However, the results found by Byun, Dowda and Pate (2012) showed a positive association between these two variables [OR 1.27 (CI 95\% 1.10-1.47)], although not for the remaining components of the lipid profile and screen time.

Considering that the study by Byun et al. (2012) is also cross-sectional, which is a limitation for establishing causality; it is thought that the variable HDL-c may not have a strong relationship with sedentary behavior. We found no other studies demonstrating this positive association in adolescents, but only significant associations with variables related to the level of physical activity.

Regarding the unexpected negative association between the BMI and the last quartile of the total aspect of sedentary behavior, we suspect the existence of a bias in the method used to classify overweight and obesity, since our subjects, despite showing sedentary behavior, were physically active and have their BMI altered. This anthropometric method does not consider fat and muscles proportions in the total body mass of individuals. It is known that the development of muscular mass is partly dependent on the environment; therefore, the individuals who are not physically active may have their lean mass reduced, affecting the BMI values.

This study has some limitations that should be taken into consideration. First, the sample was chosen intentionally. Second, the choice of instruments using indirect measurements to obtain information about level of physical activity and sedentary behaviors is not appropriate.

In spite of such limitations, this study is unique in the sense that investigates five aspects of sedentary behavior, and not just the screen time, usually utilized in the majority of studies, in addition to including information about the total time of engagement is sedentary activities during weekdays and the weekends.

\section{Conclusion}

We conclude that girls had a TC level less favorable than boys, and that there was a significant positive association between the total screen time and metabolic variables herein investigated.

This study calls attention to the need for positive changes in the life habits of adolescents. We suggest that future studies investigate the effects of intervention programs that aim to reduce behaviors that endanger the health of adolescents.

\section{References}

American Academy of Pediatrics. (2001). Children, Adolescents, and Television. Pediatrics, 107, 423-426. doi: 10.1542/ peds.107.2.423.

ABEP - Associação Brasileira de Empresas de Pesquisa. (2008). Critério de Classificação Econômica Brasil. Retrieved on September, 2012 from: http://www.abep.org/novo/ Content.aspx?ContentID=302.

Balaban, G. \& Silva, G. A. P. (2001). Prevalência de sobrepeso e obesidade em crianças e adolescentes de uma escola da rede privada de Recife. Journal of Pediatrics, 77, 96-100. doi: 10.1590/S1519-38292002000100006.

Bozza, R., Neto, A. S., Ulbrich, A. Z., Vasconcelos, I. Q. A. De, Mascarenhas, L. P. G., Brito, L. M. S., Brito, L. M. S. \& Campos, W. (2009). Circunferência da cintura, índice de massa corporal e fatores de risco cardiovascular na adolescência. Revista Brasileira e Cineantropometria e Desempenho Hu- 
mano, 11, 286-91.

Byun, W., Dowda, M. \& Pate, R. R. (2012). Associations Between Screen-Based Sedentary Behavior and Cardiovascular Disease Risk Factors in Korean Youth. Journal of Korean Medicine Science, 27, 388-394. doi: 10.3346/jkms.2012.27.4.388.

Campos, W., Stabelini Neto, A., Bozza, R., Ulbrich, A. Z., Bertin, R. L., Mascarenhas, L. P. G., Silva, S. G. da \& Sasaki, J. E. (2010) Actividad física, consumo de lípidos y factores de riesgo para aterosclerosis en adolescentes. Arquivos Brasileiros de Cardiologia, 94, 583-589.

Castillo, E. H., Borges, G., Talavera, J. O., Orozco, R., VargasAleman, C. \& Huiltrón-Bravo. (2007). Body mass index and the prevalence of metabolic syndrome among children and adolescents in two Mexican populations. Journal of Adolescence Health, 40, 521-6. doi: 10.1016/j.jadohealth. 2006.12.015

Chiara, V. L. \& Sichieri, R. (2001). Consumo alimentar em adolescentes. Questionário simplificado para avaliação de risco cardiovascular. Arquivos Brasileiros de Cardiologia, 77, 332336. doi: 10.1590/S0066-782X2007000100011.

Cole, T. Establishing a standard definition for child overweight and obesity Worldwide. International Survey. (2000). British Medical Journal (BMJ Open), 320, 1-6. doi: 10.1136/ bmj.320.7244.1240

Dietz, W. H. (1993). Therapeutic strategies in childhood obesity. Hormonal Research, 22, 589-94. doi: 10.1159/000182791.

Eaton, D. K., Kann, L., Kinchen, S., Shanklin, S., Flint, K. H., Hawkins, J., Harris, W. A. ... \& Wechsler, H. (2010). Youth Risk Behavior Surveillance - United States, 2009. MMWR Surveillance Summaries, Atlanta, 59, 1-142.

Faria, E. C., Dalpino, F. \& Takata, R. (2008) Lípides e lipoproteínas séricas em crianças e adolescentes ambulatoriais de um hospital universitário público. Revista Paulista de Pediatria, 26, 5458. doi: 10.1590/S0103-05822008000100009.

Friedewald, W. T., Levy, R. I. \& Fredrickson, D. S. (1972). Estimation of the concentration of low-density lipoprotein cholesterol in plasma, without use of the preparative ultracentrifuge. Clinical Chemistry, 18, 499-502.

Goldfield, G. S., Kenny, G. P., Hadjiyannakis, S., Phillips, P., Alberga, A. S., Saunders, T. J., ... \& Sigal, R. J. (2011). Video game playing is independently associated with blood pressure and lipids in overweight and obese adolescents. PLoS One, 6, e26643. doi: 10.1371/journal.pone.0026643

Guedes, D. P., Lopes, C. C., Guedes \& J. E. R. P. (2005). Reprodutibilidade e validade do Questionário Internacional de Atividade Física em adolescentes. Revista Brasileira de Medicina do Esporte, 11, 151-158. doi: 10.1590/S1517-869220 05000200011

Guedes, D. P. \& Guedes, J. E. R. P. (2006). Manual Prático Para Avaliação Em Educação Física. Barueri, São Paulo: $1^{\mathrm{a}}$ Ed. Manole.

Guedes, D. P. \& Guedes, J. E. R. P., Barbosa, D. S., Oliveira, J. A. \& Stanganelli, L. C. R. (2006). Fatores de risco cardiovasculares em adolescentes: indicadores biológicos e comportamentais. Arquivos Brasileiros de Cardiologia, 86, 439-50. doi: 10.1590/ S0066-782X2006000600006.

Guimarães, R., Da Silva, M. P., Mazzardo, O., Legnani, E. \& Campos, W. Validação e reprodutibilidade de questionário de atividades sedentárias para adolescentes brasileiros. Article accepted in August 2012 for publication in 2013 in Revista Brasileira de Cineatropometria e Desempenho Humano.

Hancox, R. J., Milne, B. J. \& Poulton, R. (2004). Association between child and adolescent television viewing and adult health: a longitudinal birth cohort study. Lancet, 364, 257-62. doi: 10.1016/S0140-6736(04)16675-0.

Luciano, K. S. (2009). Avaliação do perfil lipídico de crianças e adolescentes de 2 a 19 anos atendidos nas unidades ambulatoriais do Laboratório Médico Santa Luzia em Florianópolis-SC e análise comparativa entre os sexos. Dissertação (mestrado) - Universidade Federal de Santa Catarina, Centro de Ciências da Saúde, Programa de Pósgraduação em Farmácia, Florianópolis.

Moura, E. C., De Castro, C. M., Mellin, A. S. \& Figueiredo, D. B. (2000). Perfil Lipídico em escolares de Campinas, SP Brasil. Revista de Saúde Pública, 34, 499-505. doi: 10.1590/S003489102000000500010

Oliveira, T. C., Silva, A. A. M., Santos, C. J. N., Silva, J. S. \& Conceição, S. I. O. (2010). Atividade física e sedentarismo em escolares da rede pública e privada de ensino em São Luís. Revista de Saúde Pública, 44, 996-1004. doi: 10.1590/S003489102010000600003.

Pinho, R. (1999). Nível habitual de atividade física e hábitos alimentares de adolescentes durante período de férias escolares. Dissertação de Mestrado em Educação Física. Centro de Desportos da Universidade Federal de Santa Catarina, Florianópolis. 110 p.

Rover, M. R. M. \& Souza, L. C. (2007). Avaliação do perfil lipídico e sua relação com fatores de risco para a aterosclerose em crianças e adolescentes de 2 a 19 anos Florianópolis. Dissertação (mestrado). Pós Graduação em Farmácia, Universidade Federal de Santa Catarina. 96 p.

Sanders, B. H. (2006). Prevalence and treatment of metabolic syndrome in adolescents with type 2 diabetes. The Annals of Pharmacotherapy, 40, 1517-21. doi: 10.1345/aph.1H130.

Sartorio, A., Agosti, F., De Col, A., Mornati, D. \& Francescato, M. P. (2007). Prevalence of the metabolic syndrome in Caucasian obese children and adolescents: comparison between three different definition criteria. Diabetes Research and Clinical Practice, 77, 341-2. doi: 10.1016/j.diabres.2006.12. 010 .

Silva, K. S., Nahas, M. V., Peres, K. G. \& Lopes, A. S. (2009). Fatores associados à atividade física, comportamento sedentário e participação na Educação Física em estudantes do Ensino Médio em Santa Catarina, Brasil. Caderno de Saúde Pública, 25, 2187-2200. doi: 10.1590/S0102-311X2009001000010.

Sociedade Brasileira de Cardiologia. (2001). III Diretrizes Brasileiras Sobre Dislipidemias e Diretriz de Prevenção da Aterosclerose do Departamento de Aterosclerose da Sociedade Brasileira de Cardiologia. Arquivos Brasileiros de Cardiologia, 77, 1-48.

Sociedade Brasileira de Cardiologia. (2005). I Diretriz de Prevenção da Aterosclerose na Infância e na Adolescência (versão final). Arquivos Brasileiros de Cardiologia, 85, 1-36. doi: http:// dx.doi.org/10.1590/S0066-782X2005002500001.

Srinivasan, S. R., Myers, L. \& Berenson, G. S. (2002). Distribution and Correlates of Non-High-Density Lipoprotein Cholesterol in Children: The Bogalusa Heart Study. Pediatrics, 110, 29-32. doi: 10.1542/peds.110.3.e29

Stabelini Neto, A. (2011). Atividade física e síndrome metabólica em adolescentes. Tese de Doutorado - Universidade Federal do Paraná. Departamento de Educação Física, Programa de Pós-graduação em Educação Física, Curitiba, 144 págs.

Suñé, F. R., Dias-Da-Costa, J. F., Olinto, M. T. A \& Pattussi, M. P. (2007). Prevalência e fatores associados para sobrepeso e obesidade em escolares de uma cidade no Sul do Brasil. Caderno de Saúde Pública, 23, 1361-1371. doi: 10.1590/S0102- 
$311 X 2007000600011$.

Tenório, M. C. M, Barros, M. V. G, Tassitano, R. M., Bezerra, J., Tenório, J. M. \& Hallal, P. C. (2010). Atividade física e comportamento sedentário em adolescentes estudantes do ensino médio. Revista Brasileira de Epidemiologia, 13, 105-17. doi: 10.1590/S1415-790X2010000100010.

Terres, N. G., Pinheiro, R. T., Horta, B. L., Pinheiro, K. A. T. \& Horta, L. L. (2006). Prevalência e fatores associados ao sobrepeso e à obesidade em adolescentes. Revista de Saúde Pública, 40, 627-633. doi: 10.1590/S0034-89102006000 500011.

Utter, J., Scragg, R. \& Schaaf, D. (2006). Associations between television viewing and consumption of commonly advertised foods among New Zealand children and young adolescents. Public Health Nutrition. 9, 606-12. doi: 10.1079/PHN2005899

Valverde, M. A., Vítolo, M. R., Patin, R. V., Escrivão, M. A. M. S., Oliveira, F. L. C. O. \& Ancona-Lopez, F. (1999). Investigação de alterações no perfil lipídico de crianças e adolescentes obesos. Archivos Latinoamericanos de Nutrición, $49,338-43$.

World Health Organization - WHO. (2010). Global Recommendations on Physical Activity for Health. Geneva, p.160.

\section{Authors' note}

Roseane de Fátima Guimarães, Michael Pereira da Silva, and Rafael Vieira Martins are with the Physical Education Department. Federal University of Paraná. Postgraduate Programme - Master`s Degree in Physical Education. Curitiba, Paraná.

Oldemar Mazzardo is with the Physical Education Department. Federal University of Paraná. Postgraduate Programme - Post Doctorate. Curitiba, Paraná.

Wagner de Campos is with the Physical Education Department. Federal University of Paraná. Professor in the Postgraduate Programme. Curitiba, Paraná.

\section{Correspondence to:}

Roseane de Fátima Guimarães

Rua Frei Antônio de Pádua, 1573, ap. 92

Campinas, SP.

roseaneguimaraes@yahoo.com.br

Phone (19) 98436-4236

Study is part of a master's thesis.

Financial support: CAPES and CNPq.

Manuscript received on January 25, 2013

Manuscript accepted on August 18, 2013

Motriz. Journal of Physical Education. UNESP, Rio Claro, SP, Brazil, eISSN: 1980-6574, is licenced under a Creative Commons License, Version 3.0. 